\title{
The Effectiveness of Visualization, Auditory, Kinesthetic (VAK) Model toward Writing Narrative: Linguistic Intelligence Perspective
}

\section{Etika Kusumawarti}

Postgraduate Program of Elementary School Teacher Education, Postgraduate Faculty, Sebalas Maret University, Surakarta, Indonesia, etikakusuma.ek@gmail.com

\section{Slamet Subiyantoro}

Prof., Postgraduate Faculty, Sebelas Maret University, Surakarta, Indonesia, s.biyantoro@yahoo.co.id

\section{Rukayah}

Dr., Postgraduate Faculty, Sebelas Maret University, Surakarta, Indonesia, rukayah@staff.uns.ac.id

This research was a quasi-pretest-posttest design experimental study with experimental and control classes. The experimental class applied the VAK model and the control class applied the guided inquiry model. The research was conducted on fifth-grade students of primary schools in Surakarta in the academic year 2018/2019 with a sample of 114 students selected by random sampling technique. The research data was obtained by a narrative writing test instrument that had been validated by linguists and evaluation experts before tested. The results showed the mean score of narrative writing skills gained in the experimental class was 0.44 compared to the control class of -0.30 . The results of the independent sample t-test showed a significant difference between the experimental class and the control class with a t-value of 25.155 and a sig. (2tailed) value of $0.000<0.05$. The effect-size calculation showed that the VAK model had a high effectiveness in learning narrative writing skills, with a value of $\mathrm{d}$ $=7.58$. Based on the theory, related to learning style (visualization, auditory, kinesthetic) could enhance the increase in linguistic intelligence as an internal factor affecting narrative writing skills. Based on research findings and theories, it can be synthesized that in terms of linguistic intelligence, the VAK model is effective in improving narrative writing skills.

Keywords: narrative writing skills, linguistic intelligence, auditory kinesthetic visualization, visualization, auditory, kinesthetic 


\section{INTRODUCTION}

Writing is a way of communication between one individual and another through written media (Tomašč́ková, 2009), it means that an individual can communicate indirectly through written media. Mohammad \& Hazarika (2016) explains that writing skill is the highest language skills that is aligned with brain development and language involvement. It means that writing as a center for the implementation of various knowledge gained by listening, reading and speaking activities. Through writing, a person can tell an event that has been experienced, seen, felt, and heard (Luardini \& Asi, 2014). Through writing, someone can convey ideas, opinion, and thoughts. This is following Amutha \& Philomina, (2015) states that writing is an active and constructive thought process in which the writer constructs meaning. This is also a form of reciprocity that occurs between writers and readers through the text. Writing is an important literacy aspect that supports understanding, critical and innovative thinking in various aspects and needs to be developed to improve learning outcomes (Amutha \& Philomina, 2015; Alqurashi, 2015). Therefore, writing skill must be mastered from an early age by individuals. Concerning formal education, writing activities must be taught starting from the primary school level.

Based on observational studies and interviews conducted, the facts found that the existence of skills that were still weak and difficult to be mastered by fifth grade students of primary schools, namely writing skills. This was evidenced by the mean score of writing skills of students who have not reached the standard of Minimum completeness (KKM) yet, which was only 73.22. As many as $68 \%$ of students had not reached the KKM yet, meaning that of 51 students as many as 34 students had not been able to write well. Problems related to writing skills include difficulty in organizing language, difficulty in expressing ideas due to limited vocabulary, and lack of student creativity. By findings based on data obtained from the Global Creativity Index (GCI), in 2015 the index of creativity of students in Indonesia ranked 115 out of 139 (Florida, Mellander, \& King, 2015). Besides, based on PISA data (Program for International Student Assessment) in 2015 regarding reading performance, Indonesia was in the lowest rank (OECD, 2015). These results indicated that the interest in reading among students in Indonesia needed to be addressed and improved. The low interest of students in reading is a factor in the lack of vocabulary mastered by students, whereas in all language skills and other language components vocabulary plays an important role (Putri, 2013; Mehta, 2009). It is in line with difficulties in one's writing skills according to (Dar \& Khan, 2015; Haider, 2012) including academic background, personal interests of the writer, psychological phenomena, cognitive (ability to develop ideas, use of vocabulary, syntax, coherence) and linguistic intelligence. Fareed, Ashraf, \& Bilal (2017) explain that ineffective learning methods and models also influence the development of students' writing skills.

The problems that derive leading to the gap between the achievement of competencies that students should have with the reality that occurs in the field. Researchers require to explore alternatives that might be done to minimize the problems that exist in the writing process. Previous research has tried to focus on problems and factors that influence 
narrative writing skills, as well as offering suggestions that are still general (Fareed et al., 2017), categorizing the factors that influence writing skills into a broader domain, for example, the inability of educators (Haider, 2012; Harmer, 2013) and the lack of interest of students (Harmer, 2013). Further research is needed to focus more on exploring problem-solving related to writing skills, one of them is through the learning process in the classroom.

The study intends to confirm the effectiveness of learning models that concern on students' linguistic intelligence as an important factor that supports writing skills. Writing is one of the four language skills that should be mastered, therefore it is important if writing skills are learned early at the formal education level through learning.

\section{LITERATURE REVIEW}

Writing is a very complex activity with complex components such as the ability to develop ideas, synthesize, grammar, organize language and vocabulary, the ability to communicate and use punctuation (Brown, 2001; Amutha \& Philomina, 2015; Harmer, 2013), requiring various linguistic, cognitive, sociocultural competencies (Barkaoui, 2007) and use mental processes to construct sentence structures (Quintero, 2008). Writing skills will not come naturally to each individual, therefore it is necessary to practice repeatedly so that individuals are skilled in writing (Fajriani, Djuanda, \& Sudin, 2017; Chaniago, Badusanah, \& Embi, 2011). Improving writing skills are also important for every individual because writing is very closely related to activities in daily life. Hackathorn et al, (2011) in their research stated that linking students' personal stories with the subject matter is one effective way to increase the depth of student learning. Therefore, in this study, the researchers tried to practice the writing skills of students through stories of experiences that have been experienced in written form. Speaking of experiences, in an individual's daily life will not be separated from experience. Experience can be interpreted as something that has been experienced, lived, or felt both a long time ago and a recent one (Saparwati, 2012). Experience can also be interpreted as episodic memory, that is a memory that refers to a single event or experience that occurred or was experienced by an individual at a particular time and place that serves as an autobiographical reference (Bauer, 2016; Tulving, 1985). This can be interpreted that the experiences that occur can be told to anyone to be used and be a guide and learning for humans, both told verbally or in writing. Writing that contains experiences that have been experienced is called narrative writing.

Narration is an essay that contains a repetition of real events and relates to experiences written sequentially (Kramp \& Lee Humphreys, 2010; Justice et al, 2010). This means that what someone writes in a narrative essay contains experiences or events that have been experienced in chronological order. Suparno \& Yunus (2010) states that the purpose of writing a narrative essay is to give the reader meaning about an event so that the reader can learn from the story. To make writing that has a good readability level is certainly not an easy matter. Sometimes, the sentence we write may not be fully understood by the reader. Therefore, there is a need for continuous training or applying effective methods through classroom learning so that students are able to write properly 
and correctly. Researchers recommend one effective learning model to practice writing skills of students, one of them is by applying the Visualization, Auditory, Kinesthetic (VAK) model.

Cimermanová (2018) explains that learning styles are characteristics that are considered primarily in selecting the most appropriate learning methods, techniques, and strategies. Related to learning styles as an important consideration in choosing strategies or learning models, the researchers applied visualization, auditory, kinesthetic (VAK) models in learning writing skills since through this model, students were given the flexibility to learn according to their learning styles. The VAK model is a model that combines three learning styles namely learning by seeing (visual), learning by listening (auditory) and learning by motion and emotions (kinesthetic) (Rahmawati et al, 2017; Siregar, 2018). Learning using the VAK model emphasizes direct and fun experiences for students in a way that they like. Related to the research, the VAK model is suitable for developing students' writing skills since in this writing exercise they are allowed to develop their ideas and thoughts based on daily experiences in the form of narrative essays. It is also consistent with research that has been done by Siregar (2018) states that the VAK learning model makes learning a fast and effective process; learning models that emphasize learner's direct experience. The VAK learning model assumes that learning will be effective by paying attention to the three learning styles (Rahmawati et al, 2017). Even if a person's tendency to use only one learning style or like learning using only one learning style, learning that uses more learning styles can make students more active and learning becomes more meaningful (Gardner, 2011; Sternberg \& Zhang, 2011). It means by applying the VAK model in learning to write, students are given the flexibility to utilize the learning styles they have, either using only one learning style, combining two or even overall learning styles that they have (visualization, auditory, kinesthetic) to develop their knowledge and skills in writing, particularly writing narrative essays. The VAK model can trigger more neural pathways that strengthen student learning (DePorter, Reardon, \& Singer-Nourie, 2010), therefore the VAK model is suitable for application to learning.

Learning styles are interpreted as analytic, auditory-visual individual approaches in perceiving and processing new information (Brown, 2001; Celce-Murcia, Brinton, \& Snow, 2014). It can be stated that the learning style shows the fastest and best way for students to analyze and process information that they do not know what is already known. Each student has a different learning style. For students who tend to have a visual learning style, they prefer learning by looking at pictures, diagrams, and videos, and tend to rely on non-verbal cues such as body language in helping their understanding (Siregar, 2018; Gilakjani, 2012). This is consistent with research that has been done by Tyas \& Safitri (2017) that also explained that students visually receive and remember information or instructions by reading and do not need much verbal explanation. They tend to study on their own with books because they like to take small notes. Students who tend to auditory learning styles, they will easily learn by listening to stories or through verbal communication (Kayalar \& Kayalar, 2017; Cohen \& Wolvin, 2011). Students with auditory learning styles know how to manipulate and achieve language understanding efficiently (Tabanlığlu, 2003). Besides, they remember 
information by reading it aloud and moving their lips when reading, and like the classroom atmosphere dominated by lectures (Tyas \& Safitri, 2017). Students with kinesthetic learning styles tend to prefer learning through direct approaches (experiments), they have the characteristics of likes to move and do things in class, react positively to dynamic activities and like physical activity (Leopold, 2012; Gilakjani, 2012; Tyas \& Safitri, 2017). The characteristics of learning styles that exist in these students will later help teachers in preparing appropriate learning models for students, including as considerations in this study applying the VAK model.

Some previous studies have mentioned that the VAK model is effectively applied in learning. Rahayu, Riyana, \& Silvana (2017) in their research mentioned that there was a significant increase in creative thinking skills in the experimental class learning with the VAK model compared with the control class learning with the conventional model in Indonesian language lessons. Research conducted by Suhara (2014) which states that the VAK model is effective in improving writing skills. Besides, this model can also provide opportunities for students to actively interact with teachers and peers. Gilakjani (2012) in his research also mentioned that the VAK model can provide a positive influence on student learning outcomes by enabling the development of positive attitudes towards the language learned by students. In the research conducted by Rambe \& Zainuddin (2014) states that the VAK model provides an effect significant in students' writing skills. Besides, the research conducted by (Kusumawarti, Subiyantoro, \& Rukayah, 2018) states that the use of VAK model-based multimedia is effective in learning story listening skills because in addition to multimedia fun for students, learning with the VAK model also provides freedom for students to use style study they have.

In addition to the application of innovative models and following the characteristics of students, concerning language, the authors refer to one of the nine types of compound intelligence that is most often used, namely linguistic intelligence (Estaji \& Nafisi, 2014). The VAK model has a relationship with linguistic intelligence. Gardner (2011) states that people who have high linguistic intelligence are usually good at reading, writing, telling stories, memorizing and it turns out that they are also following the learning styles inherent in students, namely visualization learning styles (learning by memorizing), auditory (learning by listening), and kinesthetic (learning by movement/emotion). Linguistic intelligence is one of the nine kinds of compound intelligence that Howard Gardner coined. Gardner (2011) defines intelligence as the ability to solve problems encountered in life, the ability to develop problems to be solved, and the ability to make something or do something useful in life. One type of compound intelligence that is sparked by Gardner is linguistic intelligence. Linguistic intelligence is defined as sensitivity to spoken and written languages, the ability to learn new languages and the ability to use language to achieve goals (Gardner, 2011; Vincey \& Pugalenthi, 2016). This intelligence includes the ability to manipulate the syntax or structure of a language, the semantics or meaning of a language, and the use of language pragmatically or practically (Derakhshan \& Faribi, 2015). In a certain sense, people with high linguistic intelligence tend to think in words and who have the ability to use language effectively both orally and in writing (Christison, Kennedy, \& Deborah, 1999). 
It can be stated that one with high linguistic intelligence tends to be more prominent in matters relating to language, both spoken and written languages. The most basic definition of linguistic intelligence is the ability to think and use words to express thoughts. When someone uses conversation to talk to each other, they utilize linguistic intelligence (Vincey \& Pugalenthi, 2016). Likewise, with writing, writing activities are not just making letters with a pen on a piece of paper, but the media to bring up the potential in terms of organizing ideas and thoughts organically, therefore linguistic intelligence is needed in writing activities. Thus, it can be said that linguistic intelligence is very influential in students' language skills, one of which is writing skills.

Linguistic intelligence consists of (1) phonology, the ability of students to use language sounds; (2) morphology, the ability of students to obtain and choose the right vocabulary, develop it into a combination of morpheme and words; and (3) syntax, the ability of students to manage phrases, clauses and sentences that can be accepted both simple sentences and complex sentences, including the ability to compile simple essays on an ongoing basis (Halil, 2017). Findings related to intelligence linguistics include research findings conducted by Vincey \& Pugalenthi (2016). In the research on the study of linguistic intelligence and academic achievement in junior high school students, the results of the study indicate that students who have positive attitudes and good linguistic intelligence have a greater desire to obtain better academic performance. It shows one important factor that can support the achievement of the process and maximum learning outcomes. Another finding is research from Samiyan (2013) which states that students who have high linguistic intelligence develop well in verbal skills and have the sensitivity to sound, meaning, and rhythm of words. That is, they can digest and develop language better when dealing with situations related to the stimulation of spoken and written languages.

From the above explanation, related research studies focus more on the application of the VAK model and linguistic intelligence separately. However, several studies have been conducted on the relationship between general intelligence in general with student learning styles that include visual, auditory, kinesthetic. Şener \& Çokçalışkan (2018) in the research stated that there is a significant positive relationship between learning styles and combinations of intelligence in general and types of intelligence in particular. Ahanbor \& Sadighi (2014) found a statistically significant relationship between the learning styles of male and female students with multiple intelligences. Similar to Ahanbor and Sadighi, the research by Panahandeh, et al (2015) also mentioned that there was a positive relationship between learning styles and multiple intelligences in terms of sex and type of intelligence. In addition to the results of the research mentioned, there are several studies on the relationship between linguistic intelligence and learning styles . For example, research by Rezeki, Sagala, \& Damanik (2018) about the correlation between student learning styles and English linguistic intelligence. The results of his research stated that there is a significant correlation between learning styles and linguistic intelligence in high school students. In his research, Zoghi (2017) about the relationship between linguistic intelligence with learning styles on Iranian EFL learners, also mentioned that linguistic intelligence is highly correlated with VAK learning styles on students. 
Various related literature reviews show that it is rare to examine the VAK model and linguistic intelligence specifically. Therefore, as an effort to overcome the existing gaps, the researcher is interested in confirming the effectiveness of the VAK model in learning concerning the linguistic intelligence of students as one of the important factors that support writing skills.

\section{METHOD}

\section{Research Design}

This research was a quasi-experimental study with pretest-posttest control group design (Creswell, 2017). This study applied the Visualization, Auditory, Kinesthetic (VAK) model in the experimental class. In the experimental class students were taught with the steps of the VAK model consisting of preparation, delivery, training, and the appearance of results, while the control group is taught with learning that was usually applied in class. Before being given treatment in the two selected sample classes, students were given a pretest to find out the initial ability. After the treatment was done, students were given a post-test and given a score in accordance with the rubric of the narrative writing skills assessment. The results of narrative writing skills were further analyzed using SPSS 25.0 for Windows to find out the results of the descriptive pretest-posttest analysis, normality and homogeneity tests, calculation of gain scores according to Hake (2004), and independent sample t-test, and effect-size test with Cohen's d.

\section{Population and Sample}

The study population was grade V primary school students in the city of Surakarta. This research was conducted in primary schools by considering the importance of writing skills to be developed early on through formal education. Besides, material writing skills were also taught at the primary school level. The study sample was 114 grade V primary school students in the 2018/2019 school year with an average age of 11-year-old learners divided into two primary schools. Sampling was carried out by simple random sampling technique. Sampling was randomly in the population in which each member of the population had the same opportunity to become a research sample (Creswell, 2017). 61 students in the experimental class were taught through the VAK model, while other students were taught with the model commonly used by class teachers, namely guided inquiry.

\section{Research Instruments}

Narrative writing skills data is taken using a test instrument. The type of test used is a subjective test in the form of description following the material and basic competencies specified (Rahmawati, et al., 2018). The test is subjective because the item contains a set of answers with free answer formulation, requiring students to remember and organize personal ideas or things that have been learned (Lebagi, Nadrun, \& Darmawan, 2014). The test is given in the form of a request to make a narrative essay based on a particular theme by paying attention to the structure of the narrative essay according to Anderson \& Anderson (2003) orientation, complications, resolution, and koda. The instrument used was validated by linguists and evaluation experts, then empirically validated 
through a trial test which showed that the instrument used was valid and reliable. The instrument validity test was carried out using the Pearson Product Moment correlation test through SPSS 25. The analysis showed the Pearson total value Correlation with 21 students as respondents amounted to 0.553 with Pearson Correlation is positive, so it can be said that all questions are valid and can be used to collect data about narrative writing skills. Reliability tests using Cronbach's Alpha obtained 0.754 or 0.700 . Following the opinion Budiyono (2003) which states that the results of measurements that have a reliability index of 0.700 or more are good enough for their usefulness.

\section{FINDINGS}

\section{Descriptive Analysis of Pretest and Posttest Results about Narrative Writing Skills}

Descriptive analysis of the results of the pretest and posttest about narrative writing skills in the experimental and control class students are in the following table 1.

Table 1

Descriptive Analysis of Pretest and Posttest Results Narrative Writing Skills

\begin{tabular}{lllllll}
\hline Test Type & Class & N & Min Value & Max value & Mean & St.Dev \\
\hline Pretest & Control & 53 & 60 & 73 & 67.19 & 3.83 \\
& Experiment & 61 & 60 & 73 & 66.03 & 3.29 \\
Postest & Control & 53 & 60 & 73 & 67.36 & 3.28 \\
& Experiment & 61 & 75 & 86 & 81.31 & 2.63 \\
\hline
\end{tabular}

Table 1 shows the results of the descriptive analysis of narrative writing skills before and after treatment in the experimental class and the control class. The test results show that in the experimental class and the control class, the average score of the pretest is not much different, namely in the experimental class 66.03 and the control class 67.19. Pretest results show that the class used in this study has the same initial ability. Meanwhile, the average posttest score in the experimental group showed a significant increase to 81.31 , while in the control class 67.36 .

\section{Gain Analysis of the Results of Pretest and Posttest Narrative Writing Skills}

The results of the pretest and posttest were then calculated to determine the improvement in the results of the VAK model on the learning of narrative writing skills. The summary results of the calculation of the average score analysis of the results of the narrative writing skills test are presented in table 2 below.

Table 2

Table Gain Analysis Results of Pretest and Posttest Narrative Writing Skills

\begin{tabular}{lll}
\hline Class & Mean Score & Category \\
\hline Control & -0.30 & Low \\
Experimentation & 0.44 & Is \\
\hline
\end{tabular}

Table 2 explains that the average gain score in the control class is -0.30 which means it is in a low category, while in the experimental class 0.44 is included in the high category. The average gain score in the experimental class is higher than the average gain score in the control class. 


\section{Analysis of Independent Sample t-Test Test Results}

An independent sample t-test was conducted to determine the difference in the average results of narrative writing skills in the experimental and control classes. The normality test and homogeneity test which were prerequisite tests had been carried out before the t-test, the results showed normal distribution data and homogeneous variance. Furthermore, the independent sample t-test is performed by interpreting the data looking at the Assumed Equal Variances column. The results of the independent sample t-test can be seen in Table 3 below.

Table 3

Independent Sample t-Test Test Table

Group Statistics

\begin{tabular}{llllll}
\hline & Class & $\mathrm{N}$ & The mean & Std. Deviation & $\begin{array}{l}\text { Std. Error } \\
\text { Mean }\end{array}$ \\
\hline Value & Control & 53 & 67.36 & 3,288 & 452 \\
\hline \multicolumn{7}{c}{ Experiment } & 61 & 81.31 & 2,630 & .337 \\
\hline Independent Sample t-Test Test Results \\
\hline Data & $\mathrm{t}$-test for Equality of Means \\
\cline { 2 - 5 } & $\mathrm{t}$ & $\mathrm{Df}$ & Sig. (2-tailed) \\
\hline Equal variances assumed & 25,155 & 112 & .000 \\
\hline
\end{tabular}

In the group statistics table, it is known that the average results of narrative writing skills in the experimental class amounted to 81.31 while in the control class amounted to 67.36. Thus descriptive statistics can be concluded that there are differences in the average results of narrative writing skills between the experimental and control classes. Furthermore, the results of the independent sample t-test above, the Sig. (2-tailed) is $0.000<0.05$ which means $\mathrm{Ha}$ is accepted. Thus it can be interpreted that there is a significant difference in the average narrative writing skills between the experimental and control classes. This difference shows that the VAK model applied to the experimental class in learning skills narrative writing is effective in improving narrative writing skills. To find out the level of effectiveness of the application of the VAK model in learning writing skills, an effect-size calculation using Cohen's formula d.

\section{Cohen's Effect-Size Test d}

An effect-size test was conducted to determine the effectiveness of the application of the VAK model in learning to write narratives. To calculate the effect-size on the t-test Cohen's formula $\mathrm{d}$ is used as follows:

$$
\begin{aligned}
d & =\frac{\pi e-\pi c}{S g a b} \\
& =\frac{91.31-67.96}{1.94} \\
& =7.58
\end{aligned}
$$

The results of the calculation of effect-size with Cohen's $d$ show that the VAK model has a high effect on learning narrative writing skills that are equal to 7.58. 


\section{DISCUSSION}

The model of Visualization, Auditory, Kinesthetic (VAK) is applied to language learning to improve narrative writing skills. Based on the results of the Independent Sample t-Test and effect-size test, the VAK model can improve narrative writing skills. In the test results Independent Sample t-Test, 0000 shows the significant value of $<0.05$, therefore $\mathrm{H}_{0}$ is rejected and $\mathrm{H}_{\mathrm{a}}$ is accepted which means that there are differences in narrative writing skills significantly between the experimental class and control class. These differences indicate that the experimental class is more effective in improving narrative writing skills. The effectiveness of the VAK model in improving narrative writing skills calculated by Cohen's formula d on the results of the Independent Sample t-Test shows that the use of the VAK model has a great effect on learning narrative writing skills.

The effect-size test results show the effect of the treatment given to the experimental class. The treatment given refers to the learning steps that apply the Visualization, Auditory, Kinesthetic (VAK) model in language learning. The VAK model is a model that combines three learning styles namely learning by seeing (visual), learning by listening (auditory) and learning by motion and emotions (kinesthetic) (Rahmawati et al., 2017; Siregar, 2018). Language learning that takes place through the VAK model consists of four steps, namely preparation, delivery, training, and the display of results (Rose \& Nicholl, 2012; Shoimin, 2014). The results of this study are relevant to Kusumawarti, Subiyantoro, \& Rukayah (2018) states that the VAK model implemented by taking into account the steps can improve the results of listening skills in language learning. Besides, learning through the VAK model is more effective because it concerns the learning styles students have, namely learning by seeing, learning by listening, and learning by movement or emotions (Rahmawati et al., 2017; Rahayu et al., 2017).

Merging the four-step model of narrative writing VAK learning can improve students' skills in writing narrative. In the first step, teachers set up learning from setting up learning devices, conditioning classes, and motivate students so that students feel ready and passion in the following learning. According to Biggs (2003), teachers must be able to create a learning environment that facilitates learning activities that ultimately help students achieve the desired learning outcomes. Learning is done with the help of powerpoint media so that learning is more enjoyable. In setting a classroom atmosphere, student motivation refers to the extent to which students can focus on learning to achieve the best learning outcomes (Saeed \& Zyngier, 2012). Motivation is one of the important factors that need to be considered by teachers to improve learning because the teacher is one of the five main elements that can influence student motivation (Williams \& Williams, 2011; Saeed \& Zyngier, 2012; Dai \& Stenberg, 2004).

In the second step, the teacher gives apperception, stimulates students' curiosity, conveys material and stimulates students to find knowledge by utilizing their learning style. In this step, the teacher helps students to learn and find meaningful academic activities. The teacher explores the students' initial knowledge of narrative essays and asks questions about what experiences they have experienced. The teacher conveys 
material by paying attention to the learning styles students have. For students with a visual learning style, the teacher uses power points as a medium in conveying subject matter. Following research conducted by Jones (2013) that power points assist teachers in presenting key material that is considered important in learning. Power points with attractive packaging can create orderly class conditions because students focus on what the teacher has to say on the powerpoint. Besides, the teacher provides learning videos to improve student understanding. For students who tend to have a visual learning style, they prefer learning by looking at pictures, diagrams, and videos, and tend to rely on non-verbal cues such as body language in helping their understanding (Siregar, 2018; Gilakjani, 2012). This is also suitable for students with auditory learning styles because, in addition to displaying pictures, learning videos also produce sound. This is relevant to the research conducted by Kayalar \& Kayalar (2017) which states that students with auditory learning styles will easily capture information by listening, reading, or writing. They can reproduce symbols, letters, or words by hearing. Besides, Yalçinkaya, Muluk, \& Şahin (2009) explained that if students cannot analyze the sound of the language heard as a whole, it can hamper the development of written language skills. This illustrates that there is a relationship between listening activities and writing activities. When the learning process takes place, the teacher allows students to demonstrate the subject matter, which is to tell the experience that has been experienced in front of the class. For students with kinesthetic learning styles, this is appropriate because they learn to use a sensory combination. Following what was conveyed by Kumar, at al (2011) in his research that kinesthetic students liked the simulation of practice and real experience or in the form of case studies about life that had been experienced. Demonstrations are also able to break the passive classroom atmosphere and can provide a pleasant experience for students. Although the demonstration only involves a few students, other students can observe and identify it (Hackathorn et al., 2011). In the end, these learning activities will help students in recounting experiences they have experienced in narrative writing.

In the third step, the teacher guides students to integrate, absorb new knowledge and skills through group discussion activities, group presentations, as well as various ways that are adapted to the learning style of VAK learning, namely learning by seeing, listening, and movement or emotions. Discussion activities create in-depth learning because they help students to explore topics in greater depth and give time to organize and store new material in long-term memory. Hackathorn et al., (2011) \& Stewart, Myers, \& Culley (2010) state that discussion activities are active teaching techniques because they enable students to explore interests, opinions, and ideas. Besides, the discussion will help students see various issues from different perspectives, find relationships between topics, build critical thinking skills, practice student communication, and even change student personalities (Bye, 2017; Dorgu, 2016). In this step, students are allowed to discuss and try to write experiences that have been experienced in the form of narrative essays in brief following the themes given by the teacher. Students are also asked to analyze the structure of narrative essays consisting of orientation, complications, resolution, and coda. Teachers as mediators and facilitators for students maximize their role in this step to help students save their learning 
experiences in long-term memory (Jagtap, 2016; Bye, 2017). However, in guiding students the teacher must continue to respect the opinions of students and must not force their thoughts on student writing (Brown, 2001). In this step auditory students tend to be more active because they tend to like discussion activities, debates, and verbal instructions.

In the fourth step, the teacher guides students to deliver the results of the group discussion, discusses the results of the discussion and gives conclusions of the material, and guides students in applying new knowledge and skills. The role of the teacher in this step is to facilitate the question and answer activities between students on the results of the discussion delivered. The teacher also guides students in rectifying misunderstanding answers to discussions and giving conclusions on learning material.

Learning with the VAK model is suitable for improving narrative writing skills when viewed from the perspective of multiple intelligence theory because the VAK model provides opportunities for students to learn according to the learning styles they have. The VAK model is a child of the Quantum learning model and is part of the teaching and learning strategy with multiple intelligence, including linguistic intelligence. In language learning, students who have linguistic intelligence do not rule out the possibility of combining the three learning styles they have (Fathani, 2011). However, in some parts of them may be using one of the saja.Beberapa learning styles of students who sometimes have difficulty in learning the language, especially in terms of hearing, usually find it difficult to decipher a series of phonemes quickly. For students with auditory learning styles, of course, linguistic intelligence in this section will not be maximized (Gardner, 2011). Linguistic intelligence in students who tend to have kinesthetic learning styles can be characterized by several activities, one of which is children's pleasure in playing Crabble or word-making games (Kosasih, 2013). Students with kinesthetic learning styles like learning activities that involve movement and emotions. In learning with the VAK model, kinesthetic students demonstrate stories of daily experiences that directly involve auditory learning styles and linguistic intelligence. Zoghi (2017) in his research states that by paying attention to the learning styles of students it will accelerate the improvement of linguistic intelligence, which linguistic intelligence is also one of the internal factors that influence student skills in writing. Zoghi also mentioned that from the results of statistical calculations obtained, the relationship Linguistic intelligence with kinesthetic learning style shows the highest score of $60 \%$, whereas in visual and auditory learning styles it is only $20 \%$. This shows that the kinesthetic learning style of the linguistic intelligence of students is better. Some authors including Brown (2001) and Walqui (2000) have also stressed the importance of paying attention to the personality or learning styles of students in improving their skills.

\section{CONCLUSION}

Based on the analysis of the results of the study, in terms of the linguistic intelligence theory, the VAK model is effective in improving narrative writing skills. The mean score of narrative writing skills in the experimental class is 0.44 when compared to the control class of -0.30 . The gain score indicates an increase in students' understanding of narrative writing skills in the experimental class including the medium criteria and the 
control class included in the low criteria. The difference in the average results of writing skills between the experimental class and the control class can be seen from the results of the independent test sample t-test which shows that there is a significant difference between the experimental class and the control class with a t value of 25,155 and a sig. (2-tailed) value of $0,000<0.05$. The effect-size test results show that the VAK model has a high level of effectiveness in learning to write narratives that is equal to 7.58. Besides, based on relevant theories, paying attention to learning styles (visualization, auditory, kinesthetic) can accelerate the increase in linguistic intelligence as an internal factor that influences narrative writing skills. Therefore, based on the theory of linguistic intelligence, applying the VAK model is effective in improving narrative writing skills.

From the theoretical studies and research results, the implication of this study is that language teacher or class teachers should concern on learning models that can improve students' skills in writing and adjust writing assignments to be given by paying attention to the learning styles of students. The VAK model is one of the learning models that is suitable for application in language learning, particularly about writing skills. This model offers students the flexibility to utilize their learning styles, visual, auditory, and kinesthetic learning styles. Besides, applying the VAK model in learning will also accelerate the improvement of linguistic intelligence, which is also one of the internal factors that affect students' writing skills. Besides, the teacher as an important component in learning needs to create innovations in learning both the use of models, methods, and media that are appropriate to the characteristics of students so that learning objectives can be achieved to the maximum. Due to time constraints, the researchers only focus on discussing the effectiveness of the application of the VAK model in writing learning in terms of linguistic intelligence theory. Linguistic intelligence is discussed only as a supporting theory of the effectiveness of the VAK model in learning to write. Future researchers can focus their attention on other aspects that have not yet been explored in this study, maybe they can discuss eight other theories of compound intelligence or the application of the VAK model to learning mathematics, science, and so on. The limitation of this research also lies in the sampling which only represents the population at the city level. Future research is expected to be able to consider more sample sizes to obtain broader generalization capabilities.

\section{REFERENCES}

Ahanbor, Z., \& Sadighi, F. (2014). The relationship between multiple intelligences, learning styles and gender. Modern Journal of Language Teaching Methods, 4(1), 176184.

Alqurashi, F. (2015). Perspectives of Saudi EFL learners towards teacher response in writing courses. International Journal of English Linguistics, 5(5), 37-46. https://doi.org/10.5539/ijel.v5n5p37.

Amutha, S. D., \& Philomina, M. . (2015). Diagnosis of reading and writing skills in primary school students. International J. of English Language Teaching, 3(7), 1-7.

Anderson, M., \& Anderson, K. (2003). Text types in English. South Yarra: Macmillan. 
Barkaoui, K. (2007). Revision in second language writing: What teachers need to know. TESL Canada Journal, 25(1), 81. https://doi.org/10.18806/tesl.v25i1.109.

Bauer, P. J. (2016). Importance of remembering forgetting. Developmental Review: DR, 38, 146-166. https://doi.org/10.1016/j.dr.2015.07.011.Development.

Biggs, J. (2003). Aligning teaching for constructing learning John Biggs keywords what is constructive alignment? Defining the ILOs. Education, 94(11), 112106. https://doi.org/10.1063/1.3100776.

Brown, H. D. (2001). Teaching by principles: An interactive approach to language pedagogy. New York: Longman.

Budiyono. (2003). Metodologi Penelitian Pendidikan. Indonesia: Sebelas Maret U.

Bye, R. T. (2017). The teacher as a facilitator for learning - flipped classroom in a master's course on artificial intelligence. Proceedings of the 9th International Conference on Computer Supported Education (CSEDU 2017), 1(6025), 184-195. https://doi.org/10.5220/0006378601840195.

Celce-Murcia, M., Brinton, D., \& Snow, M. A. (2014). Teaching English as a second or foreign language. Heinle ELT.

Chaniago, S. M., Badusanah, J., \& Embi, M. A. (2011). Masalah Pengajaran Kemahiran Berbahasa di Sekolah di Indonesia. Jurnal Pendidikan Bahasa Melayu, 1(1), 109-122.

Christison, Kennedy, M. A., \& Deborah. (1999). Multiple intelligences: Theory and Practice in Adult ESL . ERIC Digest, ED441350, 1-8.

Cimermanová, I. (2018). The effect of learning styles on academic achievement in different forms of teaching. International Journal of Instruction, 11(3), 219-232. https://doi.org/10.12973/iji.2018.11316a.

Cohen, S. D., \& Wolvin, A. D. (2011). Listening to stories: An initial assessment of student listening characteristics. Listening Education, 3(2), 16-25.

Creswell, J. W., \& Creswell, J. D. (2017). Research design: Qualitative, quantitative, \& mixed methods approaches. SAGE.

Dai, D. Y., \& Stenberg, R. J. (2004). Motivation, emotion, and cognition: Integrative perspectives on intellectual functioning and development. Mahwah, N.J: Lawrence Erlbaum Associaties.

Dar, M. F., \& Khan, I. (2015). Writing anxiety among public and private sectors Pakistan undergraduate university students. Pakistan J. of Gender Stu., 10(1), 121-136.

DePorter, B., Reardon, M., \& Singer-Nourie, S. (2010). Quantum teaching: Practice Quantum learning in classrooms. Bandung, Indonesia: Kaifa.

Derakhshan, A., \& Faribi, M. (2015). Multiple intelligences: Language learning and teaching. Int. Journal of English Linguistics, 5(4). https://doi.org/10.5539/ijel.v5n4p63. 
Dorgu, T. E. (2016). Different teaching methods: A panacea for effective curriculum implementation in the classroom. International Journal of Secondary Education, 3(6), 77. https://doi.org/10.11648/j.ijsedu.s.2015030601.13.

Estaji, M., \& Nafisi, M. (2014). Multiple intelligences and their representation in the EFL young learners' textbooks. International Journal of Research Studies in Language Learning, 1(1), 61-72. https://doi.org/10.5861/ijrsll.2014.731.

Fajriani, R., Djuanda, D., \& Sudin, A. (2017). Meningkatkan Keterampilan Menulis Paragraf Melalui Penerapan Model Pembelajaran Concept Sentence Dengan Permainan Detective Sherlock Holmes and the Adventure Book. Jurnal Pena Ilmiah, 2(1), 161170. https://doi.org/10.23819/jpi.v2i1.9649.

Fareed, M., Ashraf, A., \& Bilal, M. (2017). ESL learners' writing skills: Problems, factors and suggestions. Journal of Education \& Social Sciences, 4(2), 83-94. https://doi.org/10.20547/jess0421604201.

Fathani, A. H. (2011). Student Learning styles in solving mathematical problems based on multiple intelligence. State University of Malang.

Florida, R., Mellander, C., \& King, K. (2015). The global creativity index 2015. Martin Prosperity Institute. Retrieved from http://martinprosperity.org/media/Global-CreativityIndex-2015.pdf.

Gardner, H. (2011). Howard Gardner frames of mind, the theory of multiple intelligences. United States of America: Basic Books.

Gilakjani, A. P. (2012). Visual, auditory, kinaesthetic learning styles and their impacts on English language teaching. Journal of Studies in Education, 2(1), 104. https://doi.org/10.5296/jse.v2i1.1007.

Hackathorn, J., Solomon, E. D., Blankmeyer, K. L., Tennial, R. E., \& Garczynski, A. M. (2011). Learning by doing: An empirical study of active teaching techniques. The Journal of Effective Teaching, 11(2), 40-54.

Haider, G. (2012). An insight into di_culties faced by Pakistani student writers: Implications for teaching of writing. J. of Educational and Social Research, 2(3), 17-27.

Hake, R. . (2004). Analyzing change/gain score. CA, USA: Indiana University.

Halil, N. I. (2017). The Actualization of literary learning model based on verballinguistic intelligence. International Journal of Education and Literacy Studies, 5(4), 42. https://doi.org/10.7575/aiac.ijels.v.5n.4p.42.

Harmer, J. (2013). Thinking about language teaching: Selected articles. ELT Journal, 67(2), 250-253. https://doi.org/10.1093/elt/cct002.

Jagtap, P. (2016). Teachers role as facilitator in learning. Scholarly Research Journals, 3(17), 3903-3905. Retrieved from www.srjis.com.

Jones, A. M. (2013). The use and abuse of powerpoint in teaching and learning in the 
life sciences: A personal overview. Bioscience Education, 2(1), 1-13. https://doi.org/10.3108/beej.2003.02000004.

Justice, L. M., Bowles, R., Pence, K., \& Gosse, C. (2010). A scalable tool for assessing children's language abilities within a narrative context: The NAP (Narrative Assessment Protocol). Early Childhood Research Quarterly, 25(2), 218-234. https://doi.org/10.1016/j.ecresq.2009.11.002.

Kayalar, F., \& Kayalar, F. (2017). The effects of auditory learning strategy on learning skills of language learners (Students' Views). IOSR Journal Of Humanities And Social Science (IOSR-JHSS, 22(10), 4. https://doi.org/10.9790/0837-2210070410.

Kosasih, N. (2013). Quantum learning and optimization of intelligence. Bandung, Indonesia: Alfabeta.

Kramp, M. K., \& Lee Humphreys, W. (2010). Narrative, self-assessment, and the reflective learner. College Teaching, 41(3), 83-88. https://doi.org/10.1080/87567555.1993.9926784.

Kumar, L. R., Voralu, K., Pani, S., \& Sethuraman, K. (2011). Association of kinesthetic and read-write learner with deep approach learning and academic achievement. Canadian Medical Education Journal, 2(1), 23-27.

Kusumawarti, E., Subiyantoro, S., \& Rukayah. (2018). The use of visualization, auditory, kinesthetic (VAK) Model - based multimedia for story listening skill on fifth graders of elementary school. Edutech, 17(3), 351-365.

Lebagi, D., Nadrun, \& Darmawan. (2014). Analyzing difficulty level of subjective test. E-Journal of English Language Teaching Society (ELTS), 2(2), 1-14.

Leopold, L. (2012). Prewriting tasks for auditory, visual, and kinesthetic learners. TESL Canada Journal, 29(2), 96. https://doi.org/10.18806/tesl.v29i2.1102.

Luardini, A. M., \& Asi, N. (2014). An analysis of linguistic competence in writing texts by teachers in Palangka Raya. International Journal of English and Education, 3(2), $80-94$.

Mehta, K. N. (2009). Vocabulary teaching: Effective methodologies. The Internet TESL Journal, XV(3). Retrieved from http://iteslj.org/Techniques/Mehta-Vocabulary.html.

Mohammad, T., \& Hazarika, Z. (2016). Difficulties of learning EFL in KSA: Writing skills in context. 6(3), 105-117. https://doi.org/10.5539/ijel.v6n3p105.

OECD. (2015). Reading performance (PISA). OECD

Panahandeh, E., Khoshkhoonejad, A., Mansourzadeh, N., \& Heidari, F. (2015). On the relationship between Iranian EFL learners' multiple intelligences and their learning styles. Theory and Practice in Language Studies, 5(4), 784. https://doi.org/10.17507/tpls.0504.14.

Putri, D. S. A. (2013). Pictures combination to improve students' vocabulary mastery. 
Journal of English Language Teaching, 2(2), 1-11.

Quintero, L. M. (2008). Blogging: A way to foster EFL writing. Colombian Applied Linguistics Journal, (10), 7-49. https://doi.org/10.14483/22487085.96.

Rahayu, M. D., Riyana, C., \& Silvana, H. (2017). the effectiveness of the vak (visual auditory kinesthetic) learning model applications on students creative thinking skill enchancement towards indonesian language' s subject (quasi-experimental study against students 8 th grade of Smpn 29 Bandung). Edutcehnologia, 3(2), 93-100.

Rahmawati, L. E., Suwandi, S., Saddhono, K., \& Setiawan, B. (2018). Prototype of Indonesian reading test for the foreign students. In Advances in social sicence, education and humanities research, volume 263 (pp.125-134). Atlantis Press. https://doi.org/10.2991/iclle-18.2018.20.

Rahmawati, N. D., Buchori, A., \& Hermawan, J. S. (2017). Efektivitas Visualization Auditory Kinestetic Dan Two Stay Two Stray Berbantuan Lectora Terhadap Hasil Belajar Matematika Siswa Sma. JIPMat, 2(2), 152-164. https://doi.org/10.26877/jipmat.v2i2.1979.

Rambe, H. H., \& Zainuddin. (2014). The effect of using visual, auditory, kinesthetic (VAK) learning model on students' achievement in writing recount text. J. of Eng Lang. Teach. of FBS Unimed, 3(4). https://doi.org/https://doi.org/10.24114/reg.v3i4.1385.

Rezeki, T. I., Sagala, R. W., \& Damanik, R. (2018). The correlation between students' learning styles and students' english linguistic intelligence. Jurnal Serunai Ilmu Pendidikan, 3(2), 1-6.

Rose, C., \& Nicholl, M. J. (2012). Accelerated learning for the 21st century. Bandung, Indonesia: Nuansa.

Saeed, S., \& Zyngier, D. (2012). How motivation influences student engagement: A qualitative case study. Journal of Education and Learning, 1(2), 252-267. https://doi.org/10.5539/jel.v1n2p252.

Samiyan, L. V. (2013). The relationship between linguistic intelligence and L2 learning strategies among EFL learners with intermediate level of proficiency. Journal of Literature, Languages and Linguistics, 1, 89-93.

Saparwati, M. (2012). Phenomenology study: Experience of the head of room in managing the ward in ambarawa hospital. University of Indonesia.

Şener, S., \& Çokçalışkan, A. (2018). An Investigation between multiple intelligences and learning styles. Journal of Education and Training Studies, 6(2), 125. https://doi.org/10.11114/jets.v6i2.2643.

Shoimin, A. (2014). 68 innovative learning models in the 2013 curriculum. Yogyakarta, Indonesia: Ar-Ruzz Media.

Siregar, R. (2018). Teaching model of visualisation, auditory and kinesthetic (VAK) to improve the economic education achievement. International Journal of Humanities and 
Social Science Research, 4(1), 6-10.

Sternberg, R., \& Zhang, L. (2011). Perspectives on thinking, learning, and cognitive styles. New York: Routledge.

Stewart, T. L., Myers, A. C., \& Culley, M. R. (2010). Enhanced learning and retention through "writing to learn" in the psychology classroom. Teaching of Psychology, 37(1), 46-49. https://doi.org/10.1080/00986280903425813.

Suhara, A. M. (2014). Effectiveness vak model (Visualization Auditory Kinesthetic ) in descriptive learning. SULE-IC, 448-456.

Suparno, \& Yunus, M. (2010). Basic writing skills. Jakarta, Indonesia: University of Terbuka.

Tabanlığlu, S. (2003). The Relationship between learning styles and language learning strategies of pre-intermediate EAP students. Middle East Technical University.

Tomaščíková, S. (2009). Narrative the theories and narrative discourse. Bulletin of the Transilvania University of Braşov, 2(51), 281-290.

Tulving, E. (1985). Memory and consciousness. Canadian Psychology, 26(1), 1-12. https://doi.org/10.1037/h0080017.

Tyas, P. A., \& Safitri, M. (2017). Kinesthetic learning style preferences: A survey of Indonesian EFL learners by gender. Journal of English Educators Society, 2(1), 53. https://doi.org/10.21070/jees.v2i1.688.

Vincey, D., \& Pugalenthi, D. N. (2016). A study of linguistic intelligence and academic achievement of the student at standard xi level. Shanlax International Journal of Education, 4(4), 25-31.

Walqui, A. (2000). Contextual factors in second language acquisition. ERIC Digest, ED444381, 1-6.

Williams, K. C., \& Williams, C. C. (2011). Five key ingredients for improving student motivation. Research in Higher Education Journal, 12, 1.

Yalçinkaya, F., Muluk, N. B., \& Şahin, S. (2009). Effects of listening ability on speaking, writing and reading skills of children who were suspected of auditory processing difficulty. International Journal of Pediatric Otorhinolaryngology, 73(8), 1137-1142. https://doi.org/10.1016/j.ijporl.2009.04.022.

Zoghi, R. (2017). The relationship between linguistic intelligence and visual, auditory, and kinesthetic preferences of Iranian EFL learners. Theory and Practice in Language Studies, 7(11), 1075. https://doi.org/10.17507/tpls.0711.16. 